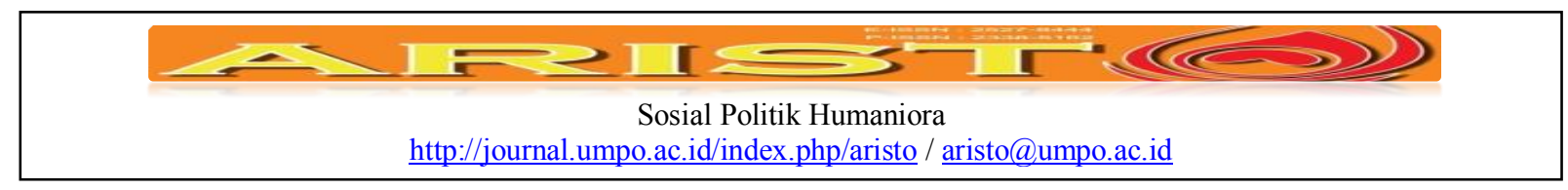

\title{
Nilai Budaya Pedagang Pasar Triwindu dalam Peningkatan Kesejahteraan Sosial
}

\author{
Fatwa Nurul Hakim \\ Balai Besar Penelitian dan Pengembangan Pelayanan Kesejahteraan Sosial, Kementerian Sosial RI \\ hakim.fatwa@yahoo.com
}

\begin{abstract}
The market has functioned as a safety net and employment provider for some communities. Traditional market as a symbol of people's prosperity in every region. This research is conducted to know the culture in Triwindu Market as one of antique market in Surakarta City. Cultural value is expected in accordance with the local wisdom of the city of Surakarta as a city that preserves the culture and cultural values as a crutch to improve the welfare of merchants this research using descriptive qualitative method with purposive sampling and unit analysis of traders antiques merchants motor parts, Heirloom traders, scales traders. Data collection using in-depth interviews. The result of the Culture which is the philosophy that developed in the merchant community and still used as one of the trading principles is "kintir ora keli" which means although following the current trade flows or developing trend but not to lose its trade identity. There is also "jeneng first new jenang" which means to be successful in trading must find a good name first in the eyes of buyers by providing the best service and quality assurance commodities, new customers will get a lot of fortune.
\end{abstract}

Keyword : Culture, Trader, Social Welfare

\begin{abstract}
Abstrak
Pasar telah berfungsi sebagai jaring penyelamat dan penyedia lapangan kerja bagi sebagian masyarakat. Pasar tradisional sebagai sebuah symbol kesejahteraan masyarakat di setiap daerah. Penelitian ini dilakukan untuk mengetahui budaya yang ada di Pasar Triwindu sebagai salah satu pasar antik di Kota Surakarta. Nilai budaya inilah diharapkan sesuai dengan kearifan local kota Surakarta sebagai kota yang melestarikan budaya dan juga nilai budaya ini sebagai penopang untuk meningkatkan kesejahteraan pedagang penelitian ini menggunakan metode deskriptif kualitatif dengan pengambilan sample secara purposive dan unit analisis pedagang barang antik pedagang onderdil motor, pedagang perpipaan, pedagang pusaka, pedagang timbangan. Pengumpulan data menggunakan wawancara mendalam. Hasil yang didapat Budaya yang yang dijadikan filosofi yang berkembang di komunitas pedagang dan masih dijadikan sebagai salah satu prinsip dagang adalah "kintir ora keli" yang artinya meskipun mengikuti arus perdagangan ataupun tren yang sedang berkembang namun tidak sampai kehilangan jati diri dagangnya. ada pula "jeneng dulu baru jenang" yang artinya untuk menjadi sukses dalam berdagang harus mencari nama baik dulu di mata pembeli dengan memberikan pelayanan yang terbaik dan jaminan mutu komoditas, baru akan diperoleh pelanggan yang mendatangkan banyak rejeki.
\end{abstract}

Kata Kunci : Budaya, Pedagang, Kesejahteraan Sosial

\begin{tabular}{|ll}
\hline Submite & : 01 Januari 2017 \\
Review & $:$ 15 April 2017 \\
Accepted & $:$ 20 Mei 2017 \\
Surel Corespondensi & : hayat@unisma.ac.id \\
\hline
\end{tabular}

Fatwa Nurul Hakim, Nilai Budaya Pedagang Pasar/01/ Vol. 5/ No. 2 Juni 2017 


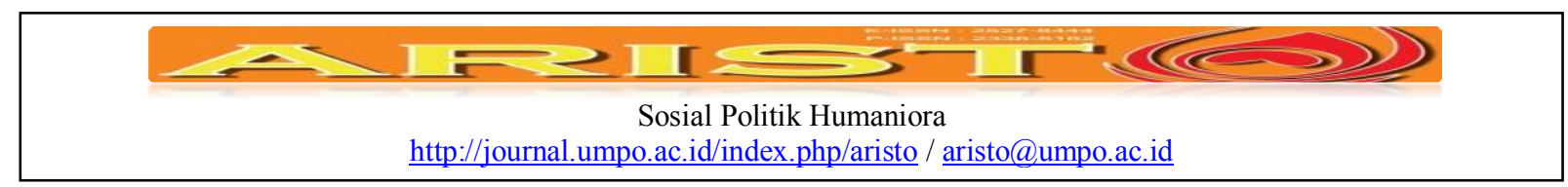

\section{Pendahuluan}

Budaya Jawa yang kental membuat Solo selalu masuk daftar destinasi wisata yang patut dikunjungi di Indonesia. Kota yang menyebut dirinya sebagai Spirit of Javatersebut menyuguhkan cerita dan benda sejarah yang selalu menarik perhatian.Bahkan, bagi kolektor barang antik, Solo menjadi surga yang menyediakan beragam benda bernilai sejarah dan suvenir jadul. Pasar Windujenar atau yang lebih dikenal sebagai Pasar Triwindu menjadi sentranya. Terletak di depan Pura Mangkunegara atau kawasan Ngarsopura di Jalan Diponegoro, pasar ini menawarkan berbagai barang antik yang boleh ditawar.

Pasar Triwindu Pada umumnya, pasar sering disebut sebagai pasar tradisional dipandang sebagai daerah yang kotor, sumber kemacetan lalu lintas dan tempat berasalnya para pelaku kriminal. Sejalan dengan bukti nyata peran pasar tradisional ini pada beberapa krisis ekonomi di Indonesia, pemerintah telah menunjukan apresiasi terhadap keberadaannya bagi para pedagang maupun bagi kota atau wilayah layanannya. Pasar tradisional ternyata mempunyai kapasitas yang kuat untuk bertahan pada situasti ekonomi makro yang tidak menentu, dan tidak terpuruk seperti aktivitas ekonomi formal atau aktivitas ekonomi yang berskala besar. Pasar telah berfungsi sebagai jaring penyelamat dan penyedia lapangan kerja bagi sebagian masyarakat. Pada sisi yang lain pasar menyediakan kebutuhan sehari hari dalam jumlah, jenis dan harga yang beragam sehingga sesuai dengan keadaan keuangan yang tidak menentu dari masyarakat pada saat krisis. Beberapa pasar menyediakan komoditas dan layanan yang menjadi bagian idengtitas kota atau wilayahnya. Dari sudut kepentingan pemerintah daerah, pasar memberikan pemasukan yang menerus dan langsung kepada kas pemerintah daerah.

Kementerian Perindustrian dan Perdagangan mencatat bahwa pada tahun 2007 terdapat 13.450 pasar tradisional dengan 12,6 juta pedagang, akan tetapi keberadaannya kian menurun seiring dengan pesatnya perkembangan pasar modern khususnya di perkotaan, dan dinamika perubahan tuntutan konsumen maupun faktor ekonomi makro - formal lainnya. Berdasarkan Survey AC Nielsen pertumbuhan Pasar Modern (termasuk Hypermarket) sebesar 31,4\%, sementara pertumbuhan Pasar Tradisional - 8,1 \% (SWA, Edisi Desember 2004). ${ }^{1}$ Bahkan perkembangan peritel modern sudah masuk hingga wilayah pinggir kota semenjak dikeluarkannya kebijakan deregulasi perdagangan pada tahun 2008. ${ }^{2}$ Jikalau tidak ada kebijakan dan upaya-upaya sistematis yang memahami karakteristik dan berpihak kepada keberadaan pasar tradisional dan pedagangnya, maka penghidupan sekitar 12,6 juta pedagang pasar tradisional 


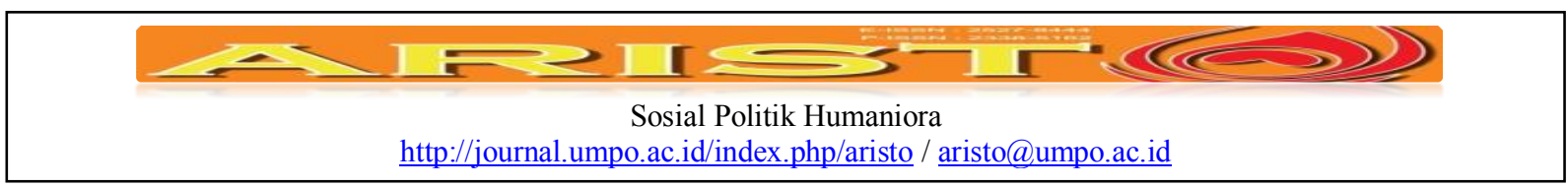

beserta keluarga, pegawai dan pemasok komoditasnya akan terancam kelangsungan kehidupannya. Dalam skala kota, pudarnya pamor dan karakter kota yang melekat pada pasar tradisional akan berdampak pada menurunya keunggulan kota - kota di Indonesia terhadap kota - kota lain setidaknya di Asia.

Pengamatan awal yang telah dilakukan di kota Surakarta yaitu di Pasar Triwindu menunjukan permasalahan adalah secara fisik pasar tradisional umumnya buruk, berkembang tanpa rencana, beroperasi melimpah sampai keluar wilayah tapaknya. Hal ini berdampak pada kemacetan lalu lintas disekitarnya, ketidaknyamanan konsumen dan operasi dari para pedagang, rawan kebakaran dan menjadi elemen buruk dari kota dan wilayahnya termasuk mendorong kekumuhan disekitarnya. Ada pasar tradisional yang sempat diperbaiki di era pasar inpres yang kehilangan identitasnya, ada pula pasar` tradisional yang telah berhasil ditata secara lebih sehat, aman, nyaman dan menunjukan peningkatan transaksi yang menerus. Secara ekonomi pasar’ tradisional sangat dinamis, masing-masing bisa meningkat dan atau menurun aktivitas ekonominya sesuai dengan komoditas dan lokasi keberadaan pasar tersebut. Ada pasar tradisional yang menunjukan perkembangan dan kekuatan daya lenting usaha yang tinggi, ada yang stagnan dan ada yang cenderung terpuruk tidak mampu bersaing dengan aktivitas ekonomi dan tuntutan layanan dari konsumennya. Secara sosial, umumnya di kota lama ada satu atau lebih pasar yang memiliki identitas kuat merepresentasikan keunggulan kotanya. Kekuatan komunitas pedagang komoditi spesifik semakin melemah, terutama yang harus bersaing dengan komoditas "modern", dan atau menuntut pengelolaan perdagangan secara lebih modern terkait perkembangan teknologi atau kemajuan higenis atau selera konsumen.

\section{Metode}

Jenis penelitian yang dipakai dalam penelitian ini adalah penelitian deskriptif kualitatif (Koentjaraningrat, 1993:129). Sebagaimana telah disebutkan dalam perumusan masalah dan tujuan penelitian, penelitian ini bertujuan untuk menggali sumber-sumber data dan informasi berkaitan dengan permasalahan penelitian dengan menempuh langkah-langkah pengumpulan data, klasifikasi dan analisis data mengenai konflik manajemen pedagang Pasar Windujenar Solo terkait adanya revitalisasi. Teknik pengumpulan data dengan wawancara mendalam, pengambilan sample dengan purposive sample, sedangkan unit analisis Windujenar yang terdiri dari beberapapedagang yaitu pedagang barang antic, pedagang onderdil motor, pedagang 


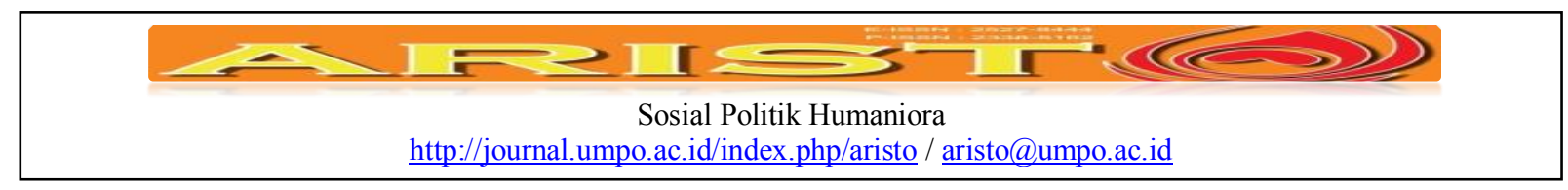

perpipaan, pedagang pusaka, pedagang timbangan. Analisis data sesuai dengan Miles dan Huberman (analisis data kualitattif, 2007) dengan reduksi data, penyajian data dan penarikan kesimpulan. Validitas data dengan trianggulasi dengan cara mengkroscek ke informan yang lain untuk mendapatkan data yang valid.

\section{Hasil dan Pembahasan}

\section{Kota Surakarta}

Kota Surakarta atau dikenal sebagaiKota Solo, merupakan sebuah dataran rendah yang terletak dicekungan lereng pegunungan Lawu dan Pegunungan Merapi dengan ketinggian sekitar $92 \mathrm{~m}$ diatas permukaan laut. Dengan luas sebesar 4.404,06 Ha, Kota Surakarta terletak diantara 110 45' 15" - 110 45' 35" Bujur Timur dan 70' 36" - 70' 56" Lintang Selatan. Kota Surakarta dibelah dan dialiri oleh 3 (tiga) buah Sungai besar, yaitu Sungai Bengawan Solo, Kali Jenes dan Kali Pepe. Batas wilayah Kota Surakarta sebelah Utara adalah Kabupaten Karanganyar dan Kabupaten Boyolali. Batas wilayah sebelah Timur adalah Kabupaten Sukoharjo dan Kabupaten Karanganyar. Batas wilayah sebelah Barat adalah Kabupaten Sukoharjo dan Kabupaten Karanganyar, sedang batas wilayah Selatan adalah Kabupaten Sukoharjo. Surakarta terbagi dalam lima wilayah kecamatan, yaitu Banjarsari, Laweyan, Serengan, Pasar Kliwon dan Jebres. ${ }^{3}$

Jumlah penduduk kota Surakarta pada tahun 2008 sebesar 522.935 jiwa dengan kepadatan penduduk sebesar $11.869 \mathrm{jiwa} / \mathrm{km}^{2}$. Dengan tingkat kepadatan tersebut, kota Surakarta menjadi kota terpadat di propinsi Jawa Tengah. Sebagai urbanized area komposisi tata guna lahan di kota ini pada tahun 2007 di dominasi oleh permukiman sebesar 62,01\%, sektor jasa sebesar 9,7\%, industri dan perusahaan sebesar 8,8\%, pertanian $5 \%$ dan lain-lain sebesar 9,07 \%. ${ }^{4}$ Sementara itu secara administratif, Kota Surakarta terdiri dari 5 (lima) wilayah kecamatan, yaitu kecamatan Laweyan, Serengan, Pasar Kliwon, Jebres dan Banjarsari. Dari kelima kecamatan ini, terbagi menjadi 51 kelurahan, 595 Rukun Warga (RW) dan 2669 Rukun Tetangga (RT). ${ }^{5}$

Posisi kota Surakarta sangat strategis yang berada pada simpul Yogyakarta - Semarang (Joglosemar) dan Yogyakarta - Surabaya. Dengan posisi tersebut, kota Surakarta merupakan pusat aktifitas perekonomian, jasa dan pendidikan di wilayah regional Subosukowonosraten (Surakarta, Boyolali, Sukoharjo, Wonogiri, Sragen dan Klaten). Kota Surakarta juga mejadi pendukung dari 2 (dua) kota besar yakni Yogyakarta dan Semarang. Selain itu, dengan adanya 2 


\begin{tabular}{|c|ccccc} 
Sosial Politik Humaniora \\
http://journal.umpo.ac.id/index.php/aristo / aristo@umpo.ac.id
\end{tabular}

(dua) keraton beserta potensi budaya yang besar, kota Surakarta menjadi salah satu pusat kebudayaan Jawa.

Basis perekonomian Kota Surakarta berdasarkan Produk Domestik Regional Bruto (PDRB) tahun 2007 didominasi oleh sektor bangunan, perdagangan, transportasi dan jasa. Pada aspek perdagangan, kota Solo memiliki komoditas lokalyang sudah sangat terkenal yakni batik. Batik sudah menjadi ikon yang melekat, sehingga pemerintah kota Surakarta memanfaatkan potensi ini dengan menggelar even Solo Batik Carnival setiap tahunnnya. Sentra-sentra pengrajin Batik di kota Surakarta yang terkenal adalah sentra batik Kampung Kauman dan sentra Batik Kampung Laweyan. Berdasarkan data Dinas Pengelolaan Pasar kota Surakarta terdapat 41 pasar yang tersebar di seluruh kota Surakarta. Adapun pasar-pasar yang tersebar di kota Surakarta dapat ditunjukkan pada peta berikut ini.

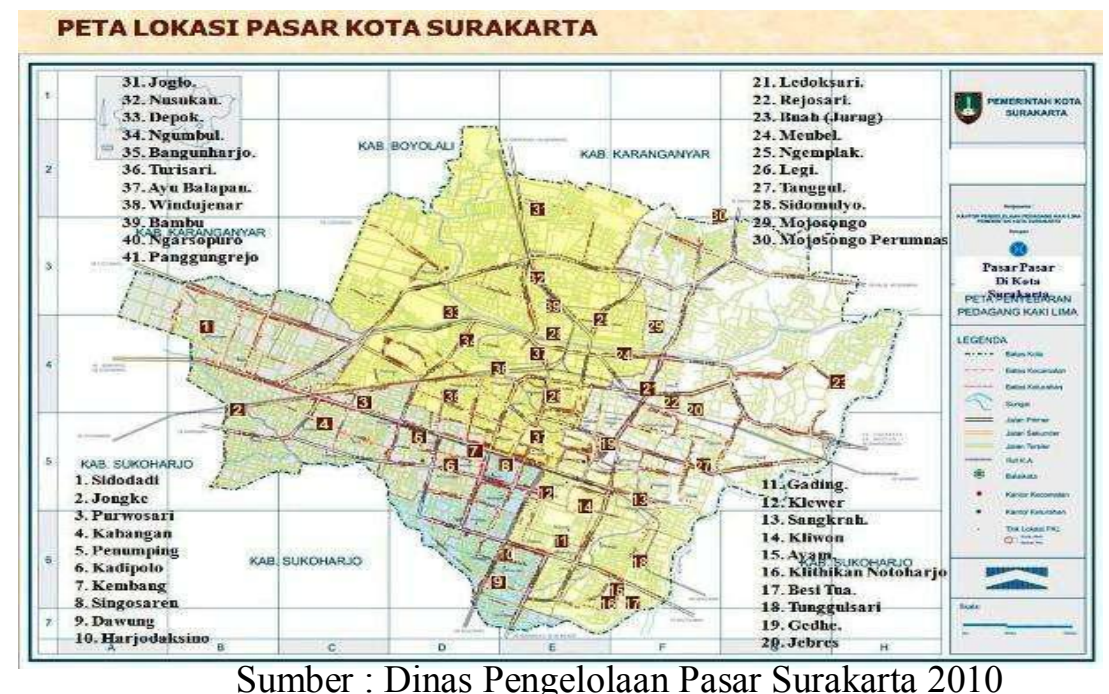

Dalam program revitalisasi pasar tradisional yang dilaksanakan terdapat sekitar 3.366 pedagang kios, 7.415 pedagang los dan 4.949 pedagang pelataran di 38 pasar tradisional. Dalam proses revitalisasi ini, seluruh biaya ditanggung oleh APBD kota Surakarta dan tidak ada biaya yang dipungut dari pedagang. Beberapa contoh lokasi pasar yang sudah direvitalisasi antara lain pasar Nusukan, pasar Kembang, pasar Sidodadi, pasar Gading, dan pasar Windujenar. Dalam proses revitalisasi ini, pedagang disiapkan dengan berbagai pembinaan agar mampu memberikan pelayanan yang optimal kepada pembeli serta dapat berperan dalam menjaga kebersihan, kenyamanan, dan keamanan pasar. 


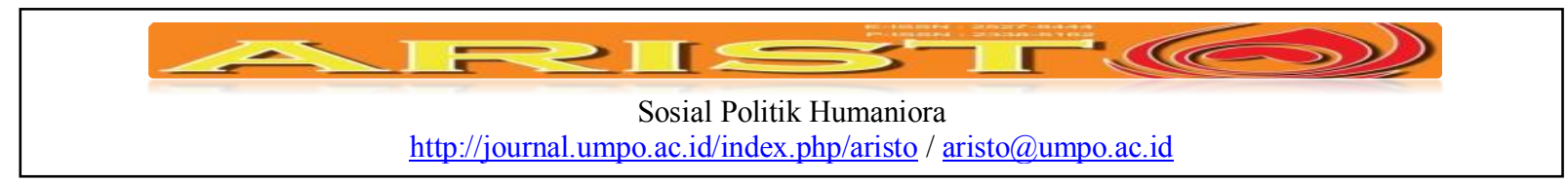

Pemerintah kota Surakarta sangat giat mempromosikan keberadaan pasar tradisional kepada berbagai pihak. Berbagai even diselenggarakan untuk menarik pengunjung dari luar kota agar berbelanja di pasar-prasar tradisional di kota Surakarta. Upaya-upaya ini menunjukkan bahwa pasar tradisional di kota Surakarta diposisikan sebagai magnet pertumbuhan ekonomi kota sekaligus inkubasi peningkatan kesejahteraan warga di kota Surakarta khususnya untuk masyarakat ekonomi lemah.

\section{Analisis kekuatan modal sosial dan Budaya di pasar Triwindu kota Solo}

Perkembangan yang pesat dari pasar tradisional di Solo tidak terlepas dari peran pemerintah kota yang juga menjadi leading actor dalam kegiatan tersebut. Mekanisme hubungan faktual antara peran pemerintah kota dalam menentukan tatanan sosial dengan keberlanjutan perdagangan di pasar tradisional kota Solo terlihat di Gambar Mekanisme hubungan modal sosial dan pemerintah kota dengan keberlanjutan perdagangan pasar tradisional di kota Solo.

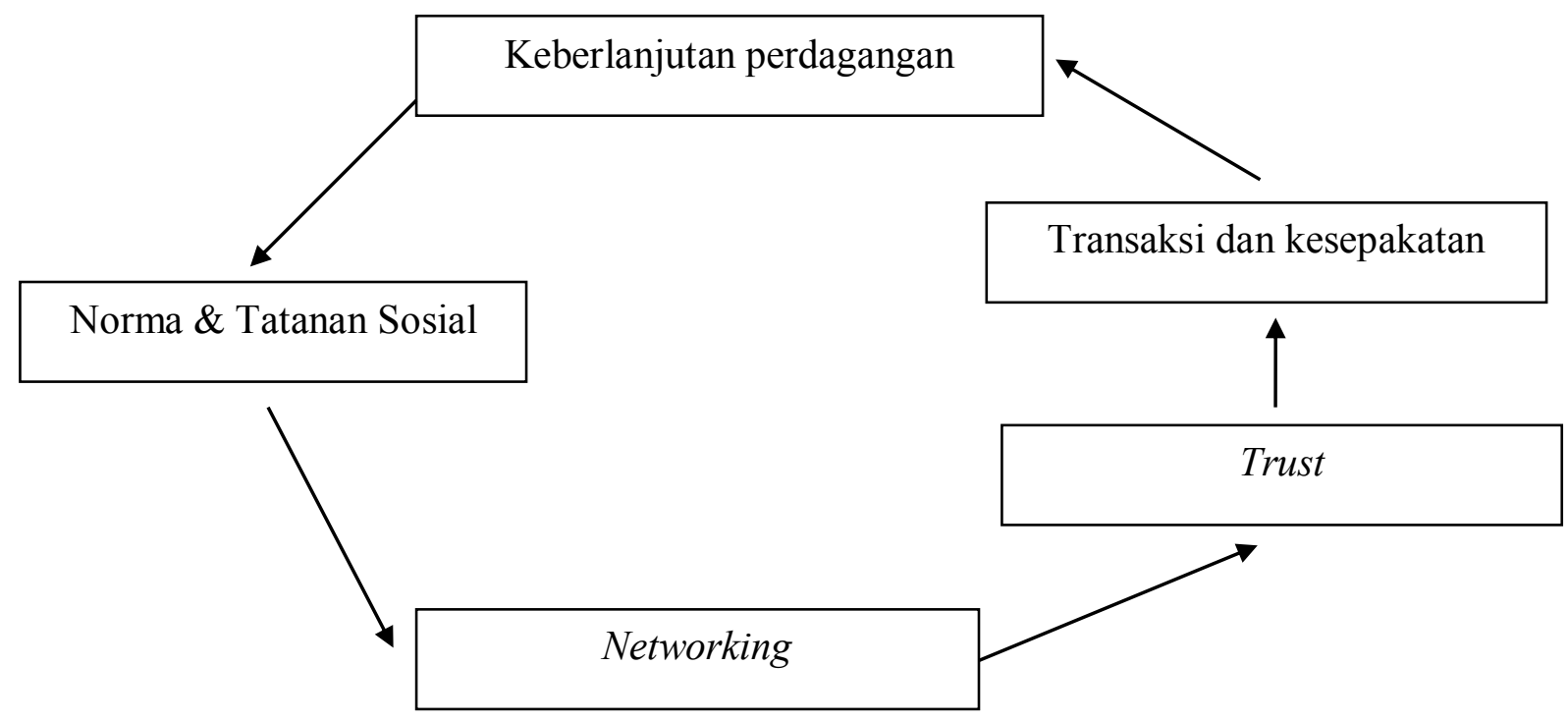

Sumber : diolah dari beberapa sumber

Norma lokal terbentuk dari pengaruh budaya, norma eksternal berupa pengakuan terhadap eksistensi pedagang sebagai saudagar kota, tatanan sosial dibentuk oleh penguasa daerah.

Trust muncul setelah jejaring dengan pemerintah terbentuk

Network yang terbentuk: network sesama pedagang beridentitas sama (bonding), network pedagang dengan supplier/pembeli beridentitas berbeda, network dengan pengelola 


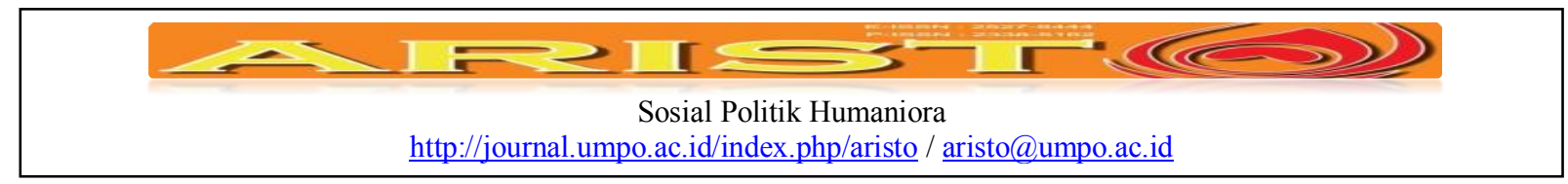

Kota Solo memiliki karakter yang berbeda dari kota Yogyakarta terkait dengan eksistensi modal sosial dan dampaknya pada keberlanjutan perdagangan di pasar tradisional. Di kota Solo, norma dan tatanan sosial akan menentukan terbentuk tidaknya jejaring antara pedagang dengan pihak-pihak lain. Dari jejaring ini baru akan muncul trust yang mendorong terjadinya proses kesepakatan atau transaksi yang berimplikasi positif terhadap sustainabilitas pasar.

Norma yang berupa filosofi budaya yang berkembang di komunitas pedagang dan masih dijadikan sebagai salah satu prinsip dagang adalah "kintir ora keli" yang artinya meskipun mengikuti arus perdagangan ataupun tren yang sedang berkembang namun tidak sampai kehilangan jati diri dagangnya. Filosofi lainnya yang menjadi prinsip penting adalah "jeneng dulu baru jenang" yang artinya untuk menjadi sukses dalam berdagang harus mencari nama baik dulu di mata pembeli dengan memberikan pelayanan yang terbaik dan jaminan mutu komoditas, baru akan diperoleh pelanggan yang mendatangkan banyak rejeki.

Semua norma lokal tersebut bersifat internal atau indigenous, sementara itu norma eksternal yang sengaja ditanamkan oleh pemerintah kota belum tertangkap jelas selama observasi maupun wawancara. Norma eksternal ini ditanamkan sebagai salah satu cara menunjukkan pengakuan pemerintah kota terhadap urgensi eksistensi pasar tradisional di kota Solo. Sedangkan untuk tatanan sosial yang dimaksud dalam Gambar diatas adalah tatanan yang sengaja dibuat untuk diikuti atau dipatuhi. Tatanan yang ditanamkan secara kolaboratif mampu membentuk jejaring yang kuat, terutama jejaring yang bersifat bridging maupun linking. Network yang bersifat menjembatani atau bridging terlihat dengan adanya supplier lintas daerah (Jakarta, Pekalongan, Bali, Jawa Timur,Banyumas, Yogyakarta, Boyolali, dll) dan sebagian besar membentuk hubungan kekeluargaan, penerimaan terhadap pembeli yang berasal dari lintas profesi. Hubungan bridging ini terbentuk lebih karena dorongan kesamaan kepentingan sehingga berbagai latar belakang pembeli atau supplier tidak menjadi permasalahan. Antara pedagang dengan pembeli terbangun trust yang tinggi misalnya pembeli saat berbelanja tidak harus membayar cash dan dapat dibayarkan kapan saja meskipun dengan nominal yang besar. Fenomena ini dengan mudah ditemui di pasar Triwindu. Pedagang juga memberikan garansi mutu komoditas terhadap pembeli. Selain pembeli, hubungan bridging yang kuat terlihat dengan adanya toleransi dari supplier yang terhadap pedagang. Pada saat terjadi kebakaran di pasar 


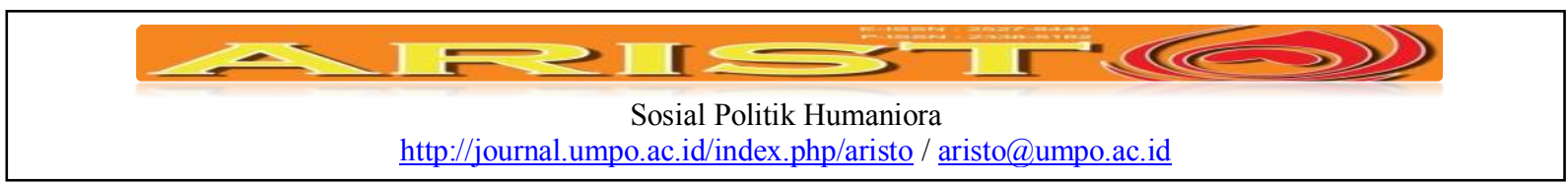

Gede, supplier tidak meminta ganti rugi pembayaran atas komoditasnya yang terbakar meskipun saat pengambilan komoditas tersebut belum dilakukan pembayaran awal.

Hubungan kemitraan atau linking network yang terbentuk dari pedagang ke pengelola dalam event-event promosi tidak terlalu kuat. Di pasar Triwindu, event promosi dikendarai oleh pemerintah dan Event organizer, sementara di pasar Gede event promosi lebih banyak melibatkan pedagang dengan kapital besar yang kemudian difasilitasi oleh pengelola pasar. Bukti lain yang menunjukkan bahwa linking network pedagang terhadap pemerintah kota tidak terlalu kuat adalah dalam event renovasi pasar, pedagang tidak banyak terlibat baik dalam analisis kebutuhan renovasi, proses perencanaan, hingga implementasinya. Hal ini tentunya memunculkan beberapa mismatched antara kebutuhan pedagang atau pasar dengan bangunan fisik hasil renovasi.

Secara umum hubungan reciprocal atau perilaku saling tolong-menolong antar pedagang cukup tinggi. Sebagaimana yang terjadi di kota Yogyakarta, jika seorang pedagang tidak memiliki barang dagangan maka dia dengan mudah akan menjualkan dagangan milik pedagang lain dimana pembayaran komoditas tersebut baru dilakukan setelah barang terjual. Selain itu antar pedagang juga tidak segan-segan mencarikan supplier untuk pedagang yang lain. Bonding network tidak terlalu menonjol kecuali di pasar Gede yang memiliki akseptabilitas yang tidak terlalu besar terhadap pedagang non-pribumi. Selain itu pedagang di pasar tersebut juga lebih memilih mendapatkan pembeli dari masyarakat lokal yang memiliki kesamaan latarbelakang suku dan budaya.

Salah satu manifestasi modal sosial yang cukup penting adalah eksistensi dan keaktifan paguyuban. Fungsi utama dari paguyuban-paguyuban tersebut adalah untuk mengelola konflik internal dan mempermudah distribusi informasi dalam internal pasar. Persatuan dari paguyubanpaguyuban pedagang tersebut adalah PAPAT SUTA atau Persatuan Paguyuban Pasar Tradisional Surakarta. Peran dan fungsi dari PAPAT SUTA ini adalah sebagai berikut:

a. Melakukan advokasi regulasi yang terkait untuk kemakmuran pasar dan pedagang

b. mengidentifikasi, malakukan tabulasi, dan mencari solusi masalah di pasar tradisional yang sifatnya lebih general

c. Menjalin network dengan supplier, pembeli, pemerintah kota, pengelola pasar untuk kepentingan pedagang

d. Menjalin kolaborasi dengan berbagai pihak terkait pasar tradisional

Fatwa Nurul Hakim, Nilai Budaya Pedagang Pasar/01/ Vol. 5/ No. 2 Juni 2017 


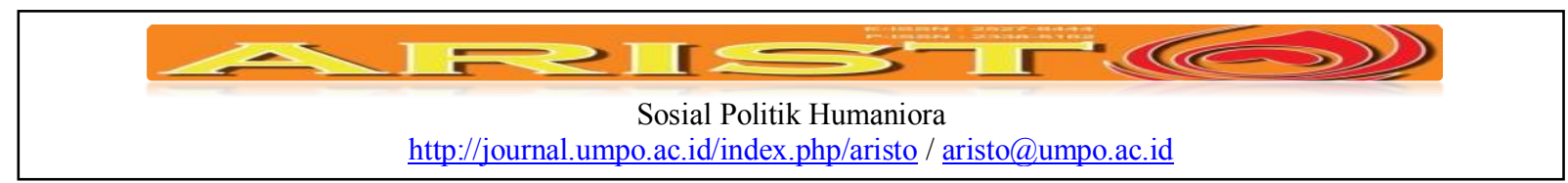

e. Menjembatani komunikasi antara pedagang/paguyuban dengan pemerintah kota (terkait berbagai program revitalisasi pasar)

f. Menyelesaikan konflik yang tidak tertangani di level paguyuban pasar

\section{Kesantunan dalam berbahasa}

Bagi orang Jawa terdapat pedoman yang bersifat konvensional yang dipahami oleh orang Jawa pada umumnya. Antara lain, berupa peribahasa seperti ajining dhiri saka lathi, ajining raga saka busana 'penghargaan terhadap diri seseorang dilihat dari cara berbicara dan berpakaian'. Hal ini dimaksudkan apabila seseorang ingin dihormati oleh orang lain harus bertutur serta bertingkah laku dan berkata secara sopan yang tidak terlepas dengan bahasa. Begitu pula dengan pedagang pasar Triwindu dalam menjalankan aktivitasnya sehari-hari, menggunakan bahasa yang santun untuk menawarkan jasanya kepada orang lain. Contoh percakapan yang menunjukkan kesantunan berbahasa di Pasar Triwindu:

Contoh (1):

Pembeli :Ni... Ni...esku ki tulung pecahna Ni!

'Ni..Ni..es ku ini tolong dipecahkan Ni!'

Penjual :O...nggih jeng, sekedhap.

'O...ya jeng, sebentar.'

Tuturan antara dua orang yaitu penutur (P) dan mitratutur (MT). Penutur adalah seorang penjual es dan mitratuturnya adalah pembeli. Percakapan berlangsung dalam situasi yang tidak resmi. Interkasi antara penjual es dan penjual tersebut terjadi di Pasar Triwindu tepatnya di angkringan sebelah timur Pasar Triwindu

Contoh (2)

Penjual : Kula betane bu. '

Saya bawakan bu.'

Pembeli : Boten sah, ra papa.

'Tidak perlu, tidak apa-apa.'

percakapan diatas diungkapkan dengan penggunaan kalimat ekspresif dan asertif untuk menghormati orang lain dengan benar-benar baik. Penghormatan terhadap orang lain akandapat terjadi hanya apabila orang dapat mengurangi kadar keuntungan bagi dirinya sendiri, dan memaksimalkan keuntungan bagi pihak lainnya. 


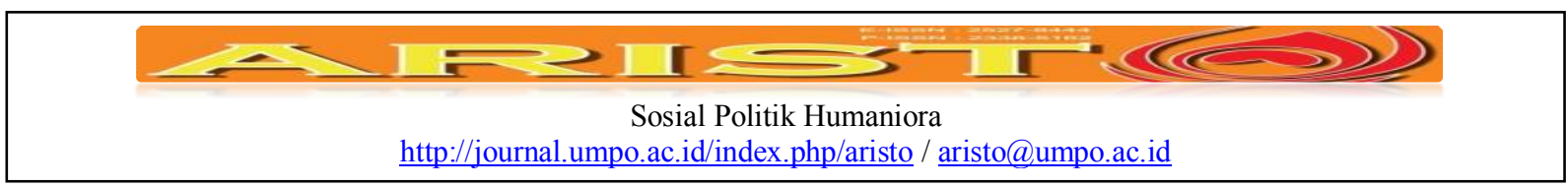

Norma lokal yang berkembang di pasar tradisional ini misalnya adalah budaya “pekewuh". Norma lokal ini merupakan nilai sosial yang terbentuk secara indigenous bukan sebagai hasil dari intervensi. Budaya ini mendorong pedagang untuk bersedia mengikuti kesepakatan bersama yang telah dicapai, mencegah konflik yang terjadi agar tidak menjadi berkepanjangan, serta mendorong pedagang membayar retribusi sesuai dengan jadwalnya. Sementara norma eksternal atau nilai-nilai sosial yang ditanamkan oleh pengelola berupa Filosofi "pasarku resik rejekiku apik" yang ditekankan oleh pengelola pasar untuk mendorong pedagang menjaga kenyamanan dan kebersihan pasar. Selain itu juga penanaman filosofi "SEMAR" yang merupakan singkatan dari Senyum, Eling dengan Yang Maha Kuasa, Manunggal diadakan paguyuban untuk persatuan, Arahan dari pengelola pasar, dan Ramah.

Dari norma ini akan terbentuk kepercayaan antar pedagang maupun pedagang dengan pihak lain yang terkait. Tingkat kepercayaan yang tinggi terhadap sesama pedagang terlihat pada saat seorang pedagang dapat melakukan jual beli dengan cara menjualkan komoditas dari pedagang lain dan pembayaran dilakukan saat komoditas telah terjual. Selain itu juga toleransi terhadap sesama pedagang sangat kuat, misalnya pada kasus para pedagang pasar Pakuncen yang berusaha membela dan mempertahankan barang dagangan salah satu pedagang lain yang dicurigai aparat menerima barang curian. Selain kepercayaan dengan sesama pedagang, kepercayaan juga terbangun antara pedagang dengan supplier. Hal ini terbukti dengan fleksibilitas pembayaran komoditas dari pedagang kepada supplier. Sementara contoh kepercayaan yang terbentuk dengan pembeli adalah pedagang tidak memaksakan pembeli untuk membayar cash. Selain itu pedagang memberikan garansi terhadap mutu komoditas untuk menjaga kepercayaan pembeli pada pedagang.

Trust yang tinggi ini berimplikasi pada terbentuknya jejaring yang kuat. Jejaring bonding ataukepaduan yang paling mudah di temukan di pasar tradisional kota yogyakarta adalah asosiasi pedagang atau paguyuban. Paguyuban ini aktif membangun kolaborasi yang tinggi baik dari anggota yang bersifat formal maupun informal.

Jejaring bridging pedagang merupakan hubungan yang bersifat kohesif dari berbagai lintas latarbelakang yang terlihat dengan adanya penerimaan pedagang terhadap pembeli maupun supplier yang berasal dari lintas etnis, lintas daerah, atau lintas profesi. Bahkan variasi pembeli pun meliputi pembeli lokal-internasional, pedesaan-perkotaan, pribumi-non pribumi. Selain itu kolaborasi bridging juga terjalin kuat dengan bank-bank konvensional seperti Bank Rakyat 


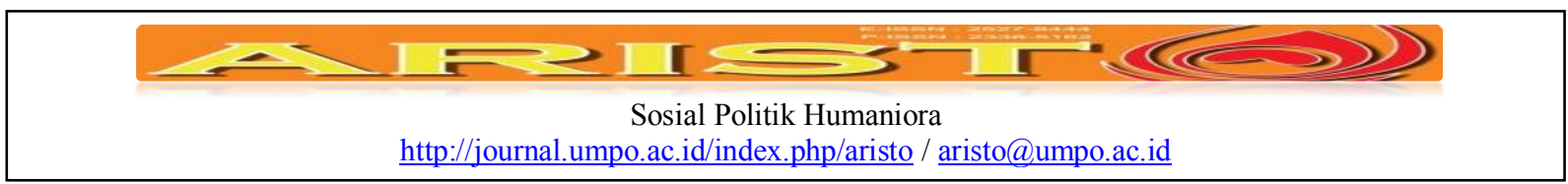

Indonesia, BankMandiri, Bank Nasional Indonesia, dll. Jejaring yang kuat ini tidak jarang berakhir pada skema hubungan kekeluargaan. Sedangkan jejaring yang bersifat kemitraan atau linking network terlihat dengan adanya koordinasi aktif antara pedagang atau paguyuban dengan pengelola pasar di setiap kegiatan, kerjasama dan berbagi peran dalam event promosi, serta pada proses penyelesaian konflik saat Lurah pasar ikut duduk bersama dalam menyelesaikan permasalahan pedagang yang tidak terselesaikan di level paguyuban. Sikap saling dukung antara pedagang dengan pengelola juga terlihat pada proses renovasi bangunan fisik pasar bringharjo dimana renovasi tersebut dilakukan oleh pedagang dan paguyuban dengan disupport oleh pengelola pasar. Dari jejaring-jejaring inilah akan muncul kesepakatan bersama atau transaksi yang menghasilkan sebuah tatanan sosial yang menekankan pada pembagian peran dan tanggungjawab dari masing-masing pihak yang terkait. Hal ini akan memberikan implikasi positif terhadap keberlanjutan perdagangan pasar tradisional.

\section{Kesimpulan}

Budaya yang dijadikan filosofi yang berkembang di komunitas pedagang dan masih dijadikan sebagai salah satu prinsip dagang adalah "kintir ora keli" yang artinya meskipun mengikuti arus perdagangan ataupun tren yang sedang berkembang namun tidak sampai kehilangan jati diri dagangnya. Filosofi lainnya yang menjadi prinsip penting adalah "jeneng dulu baru jenang" yang artinya untuk menjadi sukses dalam berdagang harus mencari nama baik dulu di mata pembeli dengan memberikan pelayanan yang terbaik dan jaminan mutu komoditas, baru akan diperoleh pelanggan yang mendatangkan banyak rejeki. Budaya sopan santun yang ditunjukkan oleh pedagang Pasar Triwindu membawa dampak pengunjung pasar merasa nyaman karena prinsip pasar tidak hanya sebagai tempat jual beli barang, tetapi juga sebagai ruang public dan untuk bersosialisasi.

Penelitian ini merekomendasikan bahwa budaya sopan santun, keakraban dengan pembeli, dan melayani dengan baik harus dilakukan oleh pedagang pasar dalam rangka untuk meningkatkan kesejahteraan pedagang itu sendiri, karena dengan pelayanan yang baik dari pembeli maka pembeli juga merasa nyaman untuk membeli barang di pasar. Pemerintah Kota Surakarta juga harus mendukung upaya untuk mengenalkan Pasar Triwindu dengan melestarikan budaya yang ada di Pasar Triwindu atau dengan membuat event-event budaya di Pasar Triwindu supaya masyarakat dari dalam Kota Solo maupun luar Kota Solo dapat lebih mengenal. 


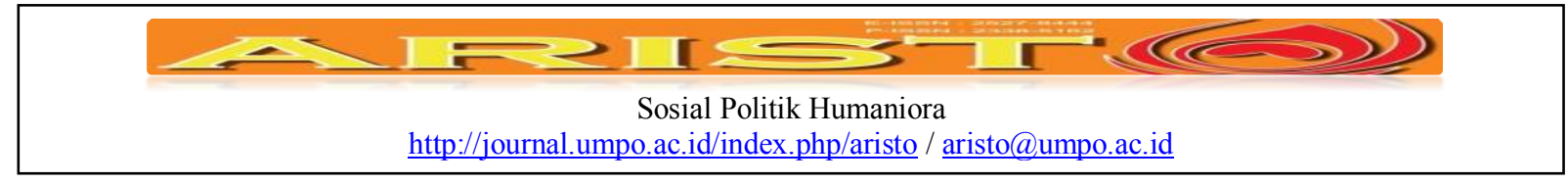

\section{Daftar Pustaka}

Hendropuspito. 1989. Sosiologi Sistemik. Yogyakarta. Kanisius..

Koentjaraningrat. 1993. Metode-Metode Penelitian Masyarakat. Jakarta. Gramedia.

Miles Mathew B, dan A. Michael Huberman. 2000. Analisis Data Kualitatif. Jakarta. UI-Press..

Moleong, Lexy J, M.A.1998. Metodologi Penelitian Kualitatif. Bandung. PT Remaja Rosdakarya..

Ritzer, George.1992. Sosiologi Ilmu Pengetahuan Berparadigma Ganda. Jakarta. Rajawali Pers..

Ritzer, George. dan Goodman J, Douglas. 2007. Teori Sosiologi Modern. Jakarta. Kencana.

Soekanto, Soerjono.2000. Sosiologi Suatu Pengantar. Jakarta. Rajawali Pers.. 